\title{
METHODICAL FOUNDATIONS OF THE PROFESSIONAL COMMUNICATIVE PREPARATION OF FUTURE PHILOLOGISTS BY MEANS OF CREATIVE WRITING
}

The article is dedicated to the theoretical and methodical investigation of the specific of the creative skills formation by means of creative writing in future philologists and improving their level of the professional communicative competence in class. The perspective of using creative translation is released as well as the requirements for their choice. It is mentioned that poems are essential resource in time of new terms learning and that in general they improve the level of the translators' professional communicative preparation. The specific of the contemporary communicative preparation of the future philologists is caused by integration processes in our society, globalization and access to the information worldwide web, the necessity in highly competent specialists in the translation field and translation. The requirement of our time is to change the approach of our educational paradigm giving priority to the communicative preparation, which points out the main aim of the teaching process at the university level. The experimentally proved system of the creative translation teaching consists of three main stages: preparation, main body and analyses. The quintessential part of the technology is the formation of imprinting in time of learning new words and being ready to write the individual creative essays. Creative translation as the main technique is directed on the foreign communicative competence formation of the future philologists.

Key words: professional communicative preparation, future philologists, creative writing, communicative competence, creative translation, communicative preparation, experimentally proved system.

\section{Introduction.}

The issue of the future professional translators training effectiveness is very complicated and multileveled process. Taking into account modern social and political challenges we can see that translation becomes one of the means of understanding on many communication levels. The history, especially modern history counts a lot of different cases, when inappropriate or shredded translation causes the situations leading to misunderstandings between the different cultural groups' representatives. In the intercultural communication spheres extending and improving conditions, modern education needs enrichment in the scientific sphere of the translators for the better ideology specificity comprehension by the native speakers. Nowadays translators face the problems related to the technology development and the globalization processes. That's why the new work forms and methods should be introduced in the professionals training process. "Few would contest the proposition that they [translators] should therefore be trained to cope with the new realities of their profession". Developing the issue, Mark Orlando points the translator to be "succeed in the role of the linguistic mediator for people of different cultures and languages. A high-qualified specialist should learn from all dimensions of the translation field: theoretical, practical and professional" [1: 11].

The analysis of the issue of creative translation usage in study was partly developed in recent scientific researches. For example the issue of poetic translation skills formation was studied by T. Hanicheva, I. Kovalska, N. Neborsyna, A. Perminova, K. Savitskiy and others. The peculiarities of the aesthetic education and the orientation of students-philologists on the music culture values, and the songwriting translation influence the creative thinking were studied by V. Basov, V. Dryapika, O. Jarkov, L. Kondratska, O. Nazaykinska. The significant aspects of the foreign languages professor creativity are explained in the works of N. Hotsulyak, N. Kichuk, T. Kohyt, L. Mykhaylova. The creative techniques are characterized in researches of such authors as G. Bush, G. Kytayhorodska, J. Kulyutkin, O. Matyushkin, I. Mehalova, V. Molyako, M. Nelke and others. Despite the list of researches mentioned above, the problem of specialists training with the help of creative translation skills formation wasn't the subject of the certain research. In our study we focused on the peculiarities of English art and lyrical creative translation.

The aim of the article is to highlight the methodological basis of the system of the professional communicative competence of future philologists by means of creative writing. The main principles of the special course training are the language orientation, functionality and situation. According to the aim, we can distinguish the tasks: to define the creative translation means application in the education of future philologists students by implementing the special course training of creative translation skills formation into the educational process.

Methods.

For the development of creative translation skills formation special course training we used such research 
methods as theoretical generalization of pedagogical experience of translation studies teaching; justification of conceptual issues and the creation of the future philologists communicative training pedagogical system model by means of creative translation; studying of documentation, plans, programs of foreign languages practical course and the theory and practice of translation; prediction (expert valuation method, experimental tasks) for defining the professional communicative competence formation level of future-philologists; pedagogical experiment for the proposed training system effectiveness checking.

\section{Research site and background on the case.}

While developing the methodical bases of the future-philologists training by means of creative translation, we worked around the point that creative activity is connected with the ability of self-development and selfpromotion. The creative translation training method includes the complex approach in the pedagogical methods [2]. During the process of students' training method creation we based on such ways of creativity development as:

- motivational-creative;

- $\quad$ creative-purpose;

- cognitive-creative;

- $\quad$ verbal-productive;

- $\quad$ emotional and creative.

The usage of these means focused on the development of basic substructures of philology of the future teachers personalities, so for the stimulation of students-philologists' creative skills we used the form of training. The introduction of special course training for the creative translation skills formation gives an opportunity to organize the study stimulating the creativity development and promote the better understanding of the world image, represented in the foreign literature [3: 63-83].

During the process of special course training we used such educational approaches and methods as:

- compositions writing;

- $\quad$ chain associations method;

- $\quad$ creative field method;

- $\quad$ phonetic opposition reception;

- $\quad$ sensory comparison reception;

- $\quad$ storytelling usage reception;

- $\quad$ individual projects.

Pedagogical system of the future philologist professional communicative competence, based on the creativity is a type of education, specific range of aims, tasks, principles, means, content, creative-innovative forms (methods, means), communicative strategies and criteria of the designed model efficiency rating [4].

During the process of the professional communicative competence (PCC) formation in future philologists the individual-creative works implementation is integrated with the technology of credit-module education. The usage of credit-module system of education has demonstrated the advantages, allowing us to stimulate students to the systematic work, to organize the student's educational activity rationally including the promotion of their independent studies organization, and to decrease the influence of such inner-psychological factors as lack of self-organization, low motivation, and reserve learning opportunities neglection.

Results.

The results show the efficacy of the training: the level of the professional communicative competence formation of the students in the experimental groups grew on 24,06 scores $(37,8 \%)$, at the same time as the professional communicative competence formation of the students of control groups grew only on 15,28 $(23,98 \%)[5]$.

Within the credit-module system, authorized special course training for the professional-communicative competence formation by means of the creative translation realized in 3 stages:

- $\quad$ I stage - diagnostic-reproductive;

- $\quad$ II stage - educational-creative;

- $\quad$ III stage - productive and creative.

At the first stage the level diagnosis motivational orientation of future philologists to professional creativity was carried out by observational methods (observation, self-observation, self-rating) of interviews, questionnaires, tests etc.

Students compared creative song and poem translations in foreign and first languages by different authors, particularly Shakespeare's sonnets, poems of Byron, William Blake. Also students compared some big parts of contemporary prose on the example of J. Rowling works of Harry Potter. The comparing process consists of finding the problematic questions which based on formed system of knowledge and it helps students to understand and adopt the new knowledge and form their own conclusions. A teacher offers general questions and problematic and searching tasks. There are some examples of general questions:

1. Which of the translations are better in transferring the mental and cultural features of the native foreign speakers? 
2. Which of the translation variants are better in transferring mood and meaning of the foreign work? Why?

3. In your opinion, which of the translations are better in presenting $\backslash$ representing the author's idea?

4. Do you see some flaws in offered translation variants? If so, which? Etc.

There are some examples of problematic and searching tasks:

1. Try to grasp the expressive dimension of the poem first. This means especially getting a clear sense of the nature and situation of the speaker.

2. Consider the relative importance of the narrative-dramatic dimension and the descriptive-meditative dimension in the poem. Is the main interest psychological or philosophical in character or in idea?

3. Reread it with particular attention to the play of language. Etc.

For irrefragable answer on some questions the students need to do research and search works that would improve their independence and interest during the educational process. For instance, once we offered the translation of the 66th Shakespeare's sonnet that was done by different authors. In the working process the students analyzed and gave an accordance estimation of translation as a form of linguistic and literate point of view as from the point of view of transferring psychological sense of the sonnet. Throughout this process, reading the poem aloud can be helpful in establishing emphases and locating problems. Parts of a poem that are not fully understood will prove troublesome in the reading. Questions of tone and attitude will become more insistent in oral performance. Thus, it is advisable to work toward a reading performance as a final check on the degree to which we have mastered situation, ideas, images, attitudes, and music. At the second stage, there was the process of student motivational orientation formation to creative solutions of educational literary and poetic text tasks. The second stage is the class and practical work. During this work we improve reproductive and creative way of thinking of future specialists. The aim of this stage is a student approximation to real / practical situations in the future professional work and formation of skills which would give the possibility to work with different genres on the high level.

In the process of class and practical work it would be great to use intensive forms and methods of work such as role game, a discussion, Socrative speaking, brainstorm and also the method of creation some problem situations, basing problematic questions which are in need of comparison, creative thinking, association establishing between the learnt material and adopted knowledge from different spheres of science and art, live experience etc.

The special places in student teaching work on the educational and creative stage take observation and analyzes during a workshop (a special form of group work that focused on active and even interactive working forms where the main role in solutions operating belongs to members of this workshop).

There were used different unexpected tasks for formation of professional skills which are needed in practical and class work. For example, students writing the creative works. One of the tasks was a translation of Joseph Brodsky's poems, which in the USA translated many of his poems from Russian into English, was awarded the Nobel Prize for Literature in 1987.The students offered their own variants of translation which further were compared with the author's translation and analyzed. According to Micaela Munoz-Calvo and Carmrn BuesaGomes a self-translation is a bright index of creative attitude of author to text where he / she allows doing some significant transformation. The main idea is to adopt a work for reader correspondent perception: "author... is concerned about a new public and a different culture. It is not surprising then, that the text becomes "another text", after all the swaps, changes, adaptations, substitutions and omissions, in short the work of a translator in freedom" [6: 22].

At the third productive and creative stage the students study how to do creative translations of different complexity level. At this stage the productive component dominates above the reproductive.

The aim of this stage is a teaching of future professionals how to use their own creative approach in practical work that foretokens an account some factors in particular situation. In the case of discrepancy between the existing translation rules of the source language and linguistic situation of the target language a student has to show an ability to find another way for solving the task. He / she should use some solutions from adopted solutions of the methodical practice or just create their own.

Taking into account the specific of work with creative translations, the technology of student preparation to writing translations of poetic works has to include such levels:

1) The preparation work during which the students make creative tasks from a teacher which are focused on skills developing of using communicative strategies; a creation of dictionary; key words; logical relations; creation of rhyme; memory card;

2) Practical assignments when students do different tasks and work in workshop;

3) Final tasks which include students writing of their own poems or other creative works based on individual and creative approach. The final level also includes an assessment of student translation acts that is done by a teacher.

For instance, one of the third stage tasks was about translating the Lewis Carroll's poem "Jabberwocky" from the story "Alice in Wonderland". For the first time the story does not have the sense and it is impossible to 
translate it. But analytical work helps to detect some features in it which by creative approach a student can create unique and bright poem translation. As an example, here is the first sonnet from it:

Twas brillig, and the slithy toves

Did gyre and gimble in the wabe:

All mimsy were the borogoves,

And the mome raths outgrabe.

This poem is a wonderful training task. The creative approach allows not only guess linguistic riddle but also to create a bright translation in native language by semantic unity interpretation, polysemy analyzes, homonym analyzes and analyzes of the poem grammatical structure [7].

At the final stage we compared the results of creative translations of students from experimental and control groups.

In that way, the results showed that the groups where special training course demonstrated better lever of the professional communicative competence formation [5].

It is important to say that since 2015 we have implemented the author's course on creative translation for the 5 -year students at the foreign languages departments of Kyiv National University of Culture and Arts and since 2017 at the Vynnytsia Pedagogical University.

\section{Conclusions.}

Thereby, the special organized system of communicative professional preparation of future philologists by creative translation methods is capable to provide the formation of the student is foreign communicative competence by developing creative qualities of personality that has positive results in efficiency of the professional preparation in educational conditions. Such system gives a synthesis of motivational, theoretical and practical readiness of future philologists.

Creative approach is the one of the most significant elements not only for the realization of corresponding translation, but for the more effective study of the foreign languages, because the creative translation allows to understand the native speakers ideology specificity better and to transmit the sense by means of the native language more precisely [3: 255-280]. While translating the artistic and poetic style compositions, the creative approach promotes other cultures representative's mentality features comprehension and understanding. Students often have difficulties with translation of poetry and fiction. It usually takes years of practice to develop the skills of creative translation and adaptation of texts to native mentality. We consider that creative methods and techniques included into the course of translation play the crucial role in improving the translation skills.

That is why the creative translation course is the tool allowing the students to see how the image of the world is formed in the other language groups representatives, finds the reflection in the language and literature.

The author's methodology of the future philologists training by means of creative translation and professional communicative strategies formation were designed and experimentally checked. It is described by the complex of the creative tasks on the foreign language materials, eclectic and heuristic manuals (words composition, dictionary formation, key words, logical ties, rhymes creation, memory cards) to manage the process of creative translation, done by the students-philologists, and to develop their communicative skills.

The developed pedagogical system determines methods, ways and forms of teaching work that promote professional communicative competence formation, the educational increase at the universities on faculties of foreign languages. It is done in the help of disclosure and development of the professional and creative students' primary abilities, the activation of their creative potential that in general would help for students to adopt and act in their future professional work. Now the mentioned course is successfully used at the higher education establishments such as Kyiv National University of Culture and Arts and Vynnytsia Pedagogical University at the foreign languages department for future philologists. In the future, we are planning to adopt this course of creative translation for students of non-philological specializations that allows, in our opinion, to improve the level of informational understanding in foreign languages and promote the understanding of cultural and mental features of the foreign representatives.

\section{REFERENCES}

1. Marc Orlando Training 21st Century Translators and Interpreters : At the Crossroads of Practice, Research and Pedagogy / Orlando Marc. - Frank \& Timme GmbH. - 2016. - 158 p.

2. Carolyn P. Sobel The Cognitive Sciences : An Interdisciplinary Approach/ Sobel Carolyn P. - University of California. - SAGE publications. - 2001. - $441 \mathrm{p}$.

3. Hansen Gyde Efforts and Models in Interpreting and Translation Research / Hansen Gyde, Chesterman Andrew, Gerzymisch-Arbogast Heidrun. - John Benjamins Publishing Company. - DOI : 10.1075/btl.80 - 2008. - 303 p.

4. Andreea Romana Năznean Developing Translation Skills in the Classroom. - LAP Lambert Academic Publishing, 2017. - Available at : https://doi.org/10.3366/tal.2016.0259.

5. RybinskaY. A. Theoretical and Methodological Foundations of the Professional Communicative Preparation of future Philologists by Means of Creative Translation ( $\mathrm{PhD}$ dissertation 13.00.04)/ RybinskaY. A. - Ternopil National Pedagogical University named after Volodymyr Hnatiuk. - Ministry of Education and Science of Ukraine. 
6. Micaela Muñoz-Calvo Translation and Cultural Identity : Selected Essays on Translation and Cross-Cultural Communication / Muñoz-Calvo Micaela, Buesa-Gómez Carmen. - Cambridge Scholars Publishing. - New edition edition, 2010.

7. Brookman H. Creativity, Translation, and Teaching Old English Poetry / H. Brookman, O. Robinson. - Translation and Literature, 25 (3), 2016. - DOI : 10.3366/tal.2016.0259. Pp. 275-297.

8. Common European Framework of Reference for Languages : Learning, Teaching and Assessment. - 2001. Trim J. L. M. - Language Policy Unit, Strasbourg.

9. Cronin Michael Translation and Globalisation / Michael Cronin. - London : Routledge, 2003.

10. Mayers Tim Writing Craft: Composition, Creative Writing, and the Future of English Studies / Tim Mayers. Pittsburgh. - University of Pittsburgh Press, 2005.

\section{Рибінська Ю. А. Методичні засади професійної комунікативної підготовки майбутніх філологів засобами креативного перекладу.}

Стаття присвячена теоретичному та методичному дослідженню специфіки формування креативних навичок засобами креативного письма у майбутніх філологів та покращенню рівня їх професійної комунікативної компетенції на занятті. Перспектива використання креативного перекладу реалізується так само, як і потреба їхнього вибору. Варто відмітити, щуо в часи вивчення нових термінів поезія є важливим джерелом і в загальному покрашує рівень професійної комунікативної підготовки перекладача.

Специфіка сучасної комунікативної підготовки майбутніх філологів спричинена інтеграчійними процесами, які відбуваються в нашому суспільстві, глобалізацією та доступом до світової інформаційної системи, потребою у висококваліфікованих спеціалістах у галузі перекладу. У наш час необхідно змінити підхід до сучасної системи освіти фокусуючи увагу на комунікативній підготовиі, яка вказує на основні иілі навчального процесу на університетському рівні. Експериментально перевірена система навчання креативного перекладу складається з трьох основних етапів: підготовка, основна частина та аналіз. Квінтесенція технологї базується на формуванні імпринтингу під час вивчення нових слів та вмінні писати індивідуальні креативні есе. Креативний переклад направлений на формування іншомовної комунікативної компетенції у майбутніх філологів.

Ключові слова: професійна комунікативна підготовка, майбутні філологи, креативне письмо, комунікативна компетенція, креативний переклад, комунікативна підготовка, експериментально перевірена система.

\section{Рыбинская Ю. А. Методические основы профессиональной коммуникативной подготовки будуццих филологов средствами креативного перевода.}

Статья посвящена теоретическому и методическому исследованию специфики формирования креативных навыков средствами креативного письма у будущих филологов и улучшению уровня их профессиональной коммуникативной компетенции на занятии. Перспектива использования креативного перевода реализуется так же, как и потребность их выбора. Стоит отметить, что во время изучения новых слов поэзия является важным источником и, в общем, улучшает уровень профессиональной коммуникативной подготовки переводчика.

Специифика современной коммуникативной подготовки будущчих филологов вызвана интеграционными процессами, которые происходят в нашем обществе, глобализацией и доступом кмировой информационной системе, потребностью в высококвалифицированных специалистах в отрасли перевода. В наше время необходимо изменить подход к современной системе образования, фокусируя внимание на коммуникативной подготовке, которое указывает на основные цели учебного процесса на университетском уровне. Экспериментально проверенная система учебы креативного перевода состоит из трех основных этапов: подготовки, основной части и анализа. Креативный перевод направленный на формирование иноязычной коммуникативной компетенции у будущих филологов.

Ключевые слова: профессиональная коммуникативная подготовка, будущуие филологи, креативное письмо, коммуникативная компетенция, креативный перевод, коммуникативная подготовка, экспериментально проверенная система. 